\title{
The Cross-Border Trade in Rice from Cambodia to Vietnam
}

\author{
Dao The Anh and Thai Van Tinh
}

\section{INTRODUCTION}

There is a paradox in the rice value chain in the Mekong Delta. Vietnam has a total paddy area of about 3.9 million ha and exported 4.8 million $t$ of rice earning USD 2.2 billion in 2016, making it one of the top three rice exporters. Over half of rice production and over $90 \%$ of exports come from the provinces in the Mekong Delta. Yet in recent years, large quantities of paddy have been imported from Cambodia across its south-eastern border. Vietnam Food Association (VFA) estimated that, in 2008-2011, an annual average of $0.8-1.0$ million $t$ of paddy were imported from Cambodia through the border provinces (VFA 2011). Purcell (2010) reported an even higher figure of about 1.86 million $t$ in 2010, of which 90\% was for the domestic market. At the Tinh Bien border gate, about 1000 t of Cambodian paddy are imported into Vietnam each day during

D. The Anh $(\bowtie)$

Vietnam Academy of Agricultural Sciences, Hanoi, Vietnam

T. Van Tinh

Centre for Agricultural Policy, Institute of Policy and Strategy for Agriculture and Rural Development, Ministry of Agriculture and Rural Development, Hanoi, Vietnam

(C) The Author(s) 2020

R. Cramb (ed.), White Gold: The Commercialisation of Rice

Farming in the Lower Mekong Basin, https://doi.org/10.1007/978-981-15-0998-8_19 
the peak season. This paddy is milled in Vietnam due to the lack of milling capacity in Cambodia. The cross-border trade in Cambodian paddy had had an impact on rice production and rice exports in the Mekong Delta.

An Giang Province has the largest rice area and output in the Mekong Delta, with a total cultivated area of 605,720 ha and production in 2011 of 3.86 million t (see Fig. 17.1 in Chap. 17). However, An Giang is also considered an ideal market for Cambodian rice, particularly from the adjacent Takeo Province (Chap. 12). This study aimed to describe the rice value chain from Takeo to An Giang, analyse the roles of the different actors in this chain, examine the impacts on rice production, processing, and consumption in An Giang, and explore ways of managing the chain for mutual benefit. The study used the value chain theory of Kaplinsky and Morris (2000) and the methodology of GTZ (2007). Fieldwork was conducted in 2012 and focused on the rice value chain through the Tinh Bien and Khanh Binh border gates in An Giang Province. A total of 238 actors were interviewed, including 3 producers, 60 traders, 70 processors, 85 retailers, and 20 consumers.

\section{BACKGROUND}

Vietnam and Cambodia share a border of $1137 \mathrm{~km}$, stretching through ten provinces in Vietnam and nine in Cambodia. An Giang Province in Vietnam shares a border of $96 \mathrm{~km}$ with the Cambodian provinces of Kandal and Takeo. An Giang has two international border gates with Cambodia: Tinh Bien-Phnom Den and Vinh Xuong-Kas Omsano. The terrain in the border region is relatively flat with many channels, creating favourable conditions for cross-border trade.

Rice production in Cambodia has experienced significant growth in recent years (Chap. 10). Rice is produced mainly in the wet season, which accounts for about $75 \%$ of total annual rice production. Most of the varieties grown in Cambodia are long-term varieties with good quality and are preferred by consumers. With total rice production reaching more than 9 million $t$ in 2014, and with a population of over 15 million people, Cambodia had a surplus of up to 4 million t of paddy for export. The Food and Agriculture Organization (FAO) reported exports of 3.61 million $t$ of paddy in 2013. While Cambodia has preferential access to many markets (e.g., Cambodia has unlimited duty-free access to the European Union market under the Everything But Arms arrangement for least-developed countries), its capacity to produce rice exports has been limited by constraints 
Table 19.1 Area, production, and yield of paddy in An Giang Province in 2011

\begin{tabular}{lrcc}
\hline Crop season & Area (ha) & Tield (t/ha) & Production $(t)$ \\
\hline Winter-Spring & 235,482 & 7.51 & $1,768,783$ \\
Summer-Autumn & 232,987 & 5.58 & $1,301,992$ \\
Autumn-Winter & 131,835 & 5.81 & 766,341 \\
Summer & 5398 & 4.32 & 23,334 \\
Total & 605,702 & 6.37 & $3,860,000$ \\
\hline
\end{tabular}

Source: DARD (An Giang Province) (2011)

in storage, processing, transportation, port facilities, and marketing (IFC 2015), hence the attraction of cross-border trade in paddy to Vietnam.

An Giang Province straddles the upper part of the Mekong Delta, with a total area of 353,676 ha and an agricultural land area of 246,821 ha (Table 19.1). Rice cultivation accounts for $82 \%$ of the agricultural land, and the total cultivated area in 2011 was 605,702 ha, implying a cropping intensity of almost 3.0 . Over $80 \%$ of the cultivated area was planted with certified varieties, mainly IR and OM varieties. ${ }^{1}$ In particular, the IR50404 variety was planted on 107,000 ha, or $17 \%$ of the cultivated area. The average yield in 2011 was $6.4 \mathrm{t} / \mathrm{ha}$ and production reached 3.86 million t. Thus, An Giang is the largest rice-producing province, not only in the Delta but also in Vietnam as a whole.

Vietnam and Cambodia have signed a number of important agreements to provide a legal basis for the development of cross-border trade. The Government of Vietnam issued Decision No. 254/2006/QD-TTg on 7 November 2006 on the management of cross-border trade, establishing preferential tax policies for imports from Cambodia to Vietnam, with rice exempt from any tax. The cross-border trade between An Giang and Takeo-Kandal increased by an average of $19 \%$ per year in the period 20062010. In 2010, the total value of goods moving across this border was estimated to be over USD 1053 million. This figure had increased by $51 \%$ over the previous year and accounted for over $50 \%$ of the total value of trade between Vietnam and Cambodia.

With regard to paddy, though it is exempt from tax, import quotas are imposed by Vietnam on Cambodian paddy and rice, including generalpurpose, aromatic, and sticky rice (MIT 2008). The combined quota was $250,000 \mathrm{t}$ of milled rice-equivalent in 2010 and 2011 , increasing to $300,000 \mathrm{t}$ in 2012 and 2013. Despite this policy, it is estimated that between 0.8 and 1.0 million t of paddy (well over the quota) are sold 
annually via the border gates in Dong Thap, Long An, and An Giang Provinces (VFA 2011). This phenomenon is partly because some Vietnamese farmers cultivate rice as share-croppers in Cambodia and bring their paddy to Vietnam to sell. Thus, the amount of paddy imported from Cambodia to Vietnam informally is large, consistent with the broader situation of unregulated cross-border trade between the two countries.

\section{Overview of the Rice Trade Between Takeo AND AN GIANG}

The broad structure of the cross-border value chain is shown in Fig. 19.1. There are three main channels by which paddy produced in Cambodia is imported into An Giang through the border gates: (1) paddy produced in Cambodia by Vietnamese farmers is taken across the border to sell to Vietnamese traders in An Giang (5\%); (2) paddy produced in Cambodia is

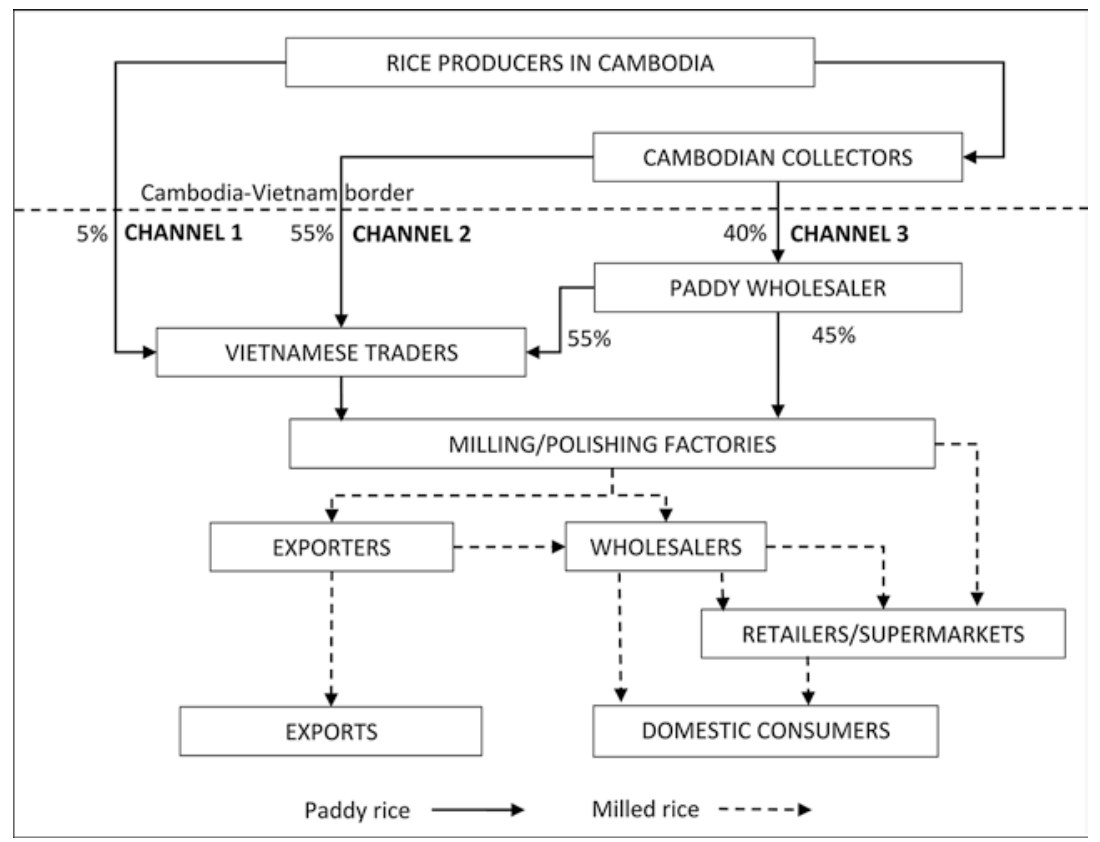

Fig. 19.1 Cross-border rice value chain between Cambodia and Vietnam 
collected by Cambodian traders and sold to traders in An Giang Province at the border $(55 \%)$; (3) Cambodian traders collect paddy and take it across the border to sell to paddy wholesalers with large granaries in An Giang (40\%).

Two main types of paddy are imported from Cambodia to Vietnam: (1) Soc paddy, including Khaodak, Khaodakmali, and Jasmine, which accounts for $80-90 \%$ - domestic consumers in Vietnam prefer Soc paddy because it is of high quality and Cambodian farmers spray few chemicals ${ }^{2} ;(2)$ Than Nong paddy, or the low-quality IR50404 variety, which accounts for 10-20\%. Once milled, this IR50404 rice is re-exported as low-quality Vietnamese rice.

There are five main reasons for the substantial flow of paddy from Cambodia into the Mekong Delta. First, Vietnamese farmers in the Delta mostly cultivate high-yielding, low-quality varieties such as IR50404, IR3217, OMl490, and OMl723 to sell to exporters. However, when production of this type of rice exceeds export demand, unsold rice is difficult to sell domestically. The domestic market, especially in the large cities, prefers high-quality aromatic rice. This is the main reason why paddy from Cambodia is imported to Vietnam through the crossborder trade.

Second, as noted above, farmers in the south-west region of Vietnam have rented land in Cambodia (in Takeo, Kandal, Prey Veng, and Svay Rieng Provinces) for rice cultivation. The cultivated area in Cambodia has expanded, and productivity has increased due to the application of intensive farming techniques from Vietnam. The cross-border trade is an essential outlet for rice cultivated by Vietnamese farmers in Cambodia. It is noteworthy that the rice produced by these farmers is not classified as either "Than Nong" or "Soc". Nevertheless, it consists of both IR50404 rice and aromatic rice varieties originating in Thailand.

Third, the difference in harvesting time between the two countries creates a demand for Cambodian rice later in the season. Vietnamese farmers use short-term varieties, so harvesting usually occurs $1-2$ months earlier than in Cambodia. Sourcing paddy from Cambodia enables the rice mills in Vietnam to keep operating efficiently.

Fourth, seed of the standard IR and OM varieties has been brought from Vietnam to be planted in Cambodia. Although the quality of the paddy grown in Cambodia is lower (smaller grains, more cracked grains, and more chalkiness) due to poorer cultivation techniques, the price is also 
much cheaper than in Vietnam, hence Vietnamese traders and factories can benefit from dealing with this low-quality crop as well as the Soc paddy.

Finally, the differences in post-harvest technology between Cambodia and Vietnam create a demand for cross-border trade to process Cambodian paddy in Vietnam. According to unofficial statistics, Vietnam has more than 100,000 rice-processing factories and 150 enterprises which are allowed to export rice. Cambodia has around 200 rice processing factories, of which only 40 are capable of processing rice to the right standard for export to international markets (Purcell 2010). In addition, Cambodian rice mills lack storage capacity, hence paddy is exported to Thailand and Vietnam. Though Cambodian processing capacity is increasing rapidly, it still represents the major constraint on exports of processed rice from Cambodia (IFC 2015).

\section{Analysing the Value Chain Actors}

\section{Producers}

The producers are mostly Cambodian farmers in Takeo, which is geographically part of the Mekong Delta (Chap. 1). These farmers traditionally cultivate the Soc paddy varieties under rainfed conditions. Yields are low, farm sizes are small, and farmers cultivate to meet family requirements, with little technical support. However, in 2002, the An Giang provincial government signed an agreement with the adjacent provinces of Takeo and Kandal to provide support in agricultural techniques. The An Giang Plant Protection Company was assigned to implement this programme by the An Giang People's Committee. Since then, the programme has organized many training events for provincial and district staff and Cambodian farmers to give them access to more intensive rice-farming techniques.

The Vietnamese producers in Takeo lease farming land from Cambodian villagers. They were previously traders who operated in the border areas and found untilled land which they requested to rent. Leases are annual or longer, up to 3-4 years. The farmers carry out land improvements and practise more capital-intensive cultivation. The result was a large increase in the supply of paddy to An Giang and the south-west border region.

Farmers use different means to transport farm inputs and outputs and consumer goods. Most (91\%) use boats, while the remaining 9\% use motorcycles and trucks. Most of the paddy is transported to Vietnam through informal trade channels using boats. 
Table 19.2 Paddy prices in the border region between An Giang and Takeo

\begin{tabular}{llllll}
\hline \multirow{2}{*}{ Actor } & $\begin{array}{l}\text { Type of } \\
\text { paddy }\end{array}$ & \multicolumn{2}{c}{ Paddy price $($ VND/kg) } & & $\begin{array}{l}\text { Paddy price in } \\
\text { domestic market }\end{array}$ \\
\cline { 3 - 5 } & & Channel 1 & Channel 2 & Channel 3 & \\
\hline Paddy producers & Soc & - & - & 5200 & - \\
& Than Nong & - & - & 4700 & 5232 \\
Traders/ & Soc & - & 5250 & 5280 & - \\
collectors & Than Nong & 5000 & 4740 & 4800 & 5330 \\
\hline
\end{tabular}

Source: CASRAD survey, March 2012

Table 19.2 shows the price of paddy traded across the Takeo-An Giang border via the three channels described above and numbered in Fig. 19.1, compared with the price of paddy produced and traded within An Giang. For the Than Nong varieties of paddy produced on a large scale in An Giang, the price of imported paddy from Cambodia was much cheaper (e.g., VND $4700 / \mathrm{kg}$ if sold through Channel 3 or VND $5000 / \mathrm{kg}$ if sold through Channel 1, compared with VND $5232 / \mathrm{kg}$ in the domestic market). Even the preferred Soc varieties were cheaper than the domestically produced Than Nong varieties. Hence, traders and milling factories could use this cross-border supply to improve their profitability.

\section{Traders}

Traders are the most important link in the cross-border value chain. Most traders used to be rice farmers but have additional experience in small business. In the 2012 survey of 60 traders, $80 \%$ were men, their average age was 40 , they averaged 9 years of education, and they had 10 years' experience in trading (Table 19.3). Their experience meant they knew how to evaluate product quality, how to deal with farmers in different locations and with different products, which factories were working efficiently, and what was happening moment-by-moment in the market. Most $(82 \%)$ operated throughout the year but the cross-border trade was mainly in November-December, the main harvest period in Cambodia. They purchased paddy along both banks of the canals that cross the border and at gathering points along the border. In the flood season, traders took their boats directly to farmers' fields in Cambodia to purchase paddy. A small number $(8 \%)$ only engaged in trading seasonally. 
Table 19.3 Characteristics of Vietnamese traders engaged in cross-border paddy trade

\begin{tabular}{ll}
\hline Characteristic & Value $(\mathrm{n}=60)$ \\
\hline Mean age (years) & 40.8 \\
Gender (\% male) & 80 \\
Education (years) & 8.7 \\
Working capital (VND $\left.\times 10^{3}\right)$ & 149,370 \\
Working capital owned by trader $(\%)$ & 72 \\
Mean length of experience in trading (years) & 9.7 \\
Proportion of traders operating throughout year $(\%)$ & 82 \\
Proportion of traders with boats $(\%)$ & 100 \\
Proportion of traders with large boats $(>33 \mathrm{t})(\%)$ & 15 \\
Mean price of large boats (VND $\left.\times 10^{3}\right)$ & 234,444 \\
Proportion of traders with medium boats $(13-33 \mathrm{t})(\%)$ & 73 \\
Mean price of medium boats $\left(\mathrm{VND} \times 10^{3}\right)$ & 193,289 \\
Proportion of traders with small boats $(<13 \mathrm{t})(\%)$ & 20 \\
Mean price of small boats $\left(\mathrm{VND} \times 10^{3}\right)$ & 85,833 \\
\hline
\end{tabular}

Source: CASRAD survey, 2012

River transport was essential for traders, hence $88 \%$ of those surveyed owned boats and 12\% rented boats (Table 19.3). However, the capacity of these boats varied with the capital resources and activities of the trader. Only 15\% of traders had large boats (> $33 \mathrm{t}$ ), most (73\%) had mediumsized boats $(13-33 \mathrm{t})$, and $20 \%$ had small boats $(<13 \mathrm{t})$; note that some had more than one boat. The traders operating inside Cambodia had the larger boats and covered longer distances from farms in Takeo to mills in An Giang.

Traders bought paddy directly from farmers (5\%), from Cambodian collectors $(55 \%)$, and from large granaries along the border. From these purchase points, they transported the paddy for processing domestically at Vietnamese mills and polishing factories.

\section{Paddy Wholesalers}

As the informal cross-border trade in paddy has grown, particularly since 2009 , the need for storage services at the border has increased. This has encouraged investment in storage granaries along the border. Once paddy is transported across the border, much of it is bulked in 6-7 paddy wholesale market places at the Tinh Bien and Khanh Binh border gates. A similar number of wholesale market places have collection stations along the 
Mekong and its channels. The wholesalers have invested in large warehouses and yards to facilitate the purchase and sale of paddy from Cambodia.

About $55 \%$ of the paddy acquired by these wholesalers is sold directly to traders and $45 \%$ is sold to milling and polishing factories through their agents. On average, over 1000 t of paddy is provided to traders each day in the peak season, who then transport this volume for processing before selling to domestic rice wholesalers. The method of transaction between Vietnamese traders and border collectors includes pre-ordering (44\%) and spot transactions $(56 \%)$.

\section{Milling/Polishing Companies}

An Giang is the largest rice producer in the Delta, so the processing sector is concentrated in this province. In 2012, there were 404 milling factories in the province with a capacity of 6.3 million $t$ of rice per year. In addition, there were 236 polishing factories with a capacity of 2.4 million $t$ of rice per year and storage for between 100 and $5000 \mathrm{t}$ each. The output of milled rice from the province was 1.87 million $t$ in 2008. The province had about 16 companies with the ability to export rice directly to other countries. One feature of the milling and polishing factories is that they only operate at full capacity during the harvest period. At other times, they lack the raw materials to maintain efficient throughput. The additional off-peak paddy supply from Cambodia enables the processing sector to optimize its operation when the domestic supply is less.

The milling operations varied greatly in scale and sophistication (Table 19.4). The owners/managers were mostly men in their $40 \mathrm{~s}$ or $50 \mathrm{~s}$ with 8-9 years of education and considerable experience, especially in the larger plants. The large rice milling and polishing factories had modern equipment and large warehouses, so the area of these factories was an order of magnitude larger than the small mills (2500-5000 $\mathrm{m}^{2}$ compared with less than $100 \mathrm{~m}^{2}$ for the small mills). The investment in equipment was also very different due to the differences in capacity and functionality, with the modern milling/polishing plants averaging USD 355,000 and requiring working capital of over USD 2 million. The mills surveyed were all privately owned and largely self-financed. However, a quarter of the milling/polishing plants producing rice for export were state-owned and had borrowed on average half the initial capital investment.

It can be seen that the investment in equipment and working capital to produce rice to export standard requires considerable experience, techni- 
Table 19.4 Characteristics of milling/polishing factories

\begin{tabular}{|c|c|c|c|c|c|}
\hline \multirow[t]{2}{*}{ Characteristic } & \multicolumn{3}{|c|}{ Size of mill } & \multirow{2}{*}{$\begin{array}{l}\text { Milling- } \\
\text { polishing plant }\end{array}$} & \multirow[t]{2}{*}{$A l l$} \\
\hline & Small & Medium & Large & & \\
\hline $\begin{array}{l}\text { Mean age of owner/ } \\
\text { manager (yrs) }\end{array}$ & 42 & 49 & 45 & 46 & 46 \\
\hline Gender ( $\%$ male $)$ & 70 & 73 & 100 & 81 & 79 \\
\hline Education (yrs) & 8.4 & 9.9 & 9.0 & 12.7 & 11.3 \\
\hline Business experience (yrs) & 6 & 11 & 15 & 12 & 11 \\
\hline Private ownership (\%) & 100 & 100 & 100 & 76 & 95 \\
\hline Total operation area $\left(\mathrm{m}^{2}\right)$ & 87 & 1550 & 2500 & 4825 & 3344 \\
\hline Mean capacity $(\mathrm{t} / \mathrm{hr})$ & 0.2 & 3.8 & 9.6 & 20.8 & 13.4 \\
\hline Loan capital at start-up (\%) & 12 & 0 & 8 & 51 & 32 \\
\hline $\begin{array}{l}\% \text { with complete white rice } \\
\text { mill }\end{array}$ & 20 & 0 & 0 & 24 & 17 \\
\hline $\begin{array}{l}\text { Value of white rice mill } \\
\text { (USD) }\end{array}$ & 7180 & 0 & 0 & 418,062 & 359,365 \\
\hline$\%$ owning dryer & 10 & 53 & 0 & 56 & 45 \\
\hline$\%$ using rubber roll huller & 40 & 53 & 75 & 49 & 50 \\
\hline$\%$ using stone disc huller & 30 & 40 & 0 & 46 & 40 \\
\hline $\begin{array}{l}\% \text { owning rice polishing } \\
\text { machine }\end{array}$ & 0 & 0 & 25 & 100 & 31 \\
\hline $\begin{array}{l}\% \text { owning discoloration } \\
\text { machines }\end{array}$ & 0 & 0 & 0 & 78 & 46 \\
\hline Mean value of mill (USD) & 5313 & 115,845 & 191,479 & 355,000 & 244,453 \\
\hline $\begin{array}{l}\text { Mean operating capital } \\
\text { (USD) }\end{array}$ & 221 & 64,784 & 119,674 & $2,224,561$ & 602,310 \\
\hline $\begin{array}{l}\% \text { of operating capital } \\
\text { borrowed }\end{array}$ & 0 & 28.6 & 39.6 & 16.8 & 17.0 \\
\hline Grain processed ( $\mathrm{t} /$ month) & 48 & 2268 & 6768 & 13,791 & 7866 \\
\hline
\end{tabular}

Source: CASRAD survey, 2012

cal knowledge, and capital. Such investment is occurring in Cambodia but is still quite limited. Hence, the processors in Vietnam are performing the milling and polishing for the hundreds of thousands of t of paddy imported from Cambodia every year.

\section{Rice Wholesalers and Retailers}

In Vietnam, rice wholesalers operate mainly in urban areas and less often in the production regions because the distance between the processors and the main consumer markets is typically very short. In fact, in produc- 
tion regions, much of the purchasing and selling of rice occurs directly between millers and retailers, without going through wholesalers. The characteristics of wholesalers surveyed in Ho Chi Minh (HCM) City are presented in Table 19.5. The wholesalers were mostly experienced and reasonably well educated. Most $(86 \%)$ owned their own warehouse, averaging $63 \mathrm{~m}^{2}$. They were almost all self-funded, with an average working capital of USD 25,500; hence it was difficult to gain entry to the wholesale market. In HCM City, $44 \%$ of wholesalers stocked rice originating from abroad, including Soc rice types from Cambodia. This is a significant number in a large rice-producing country such as Vietnam, reflecting the consumer demand for Cambodian rice.

The retailers in the study were younger than the previous actors (averaging 32 years), and there were as many women as men performing this role (Table 19.6). Despite being younger, the retailers interviewed were quite experienced, averaging almost 10 years in selling rice. About $40 \%$ had a market stall and $60 \%$ had a shop. The scale of operation for traditional retailers was generally small, with an average daily turnover of only $250 \mathrm{~kg}$ of all types of rice (modern retailers such as supermarkets do not sell Cambodian rice). However, they were widely distributed across the study area, with each traditional market having on average nine rice retail-

Table 19.5 Characteristics of urban rice wholesalers

\begin{tabular}{ll}
\hline Characteristic & Value ( $\mathrm{n}=50)$ \\
\hline Mean age (years) & 42.4 \\
Gender (\% male) & 80 \\
Education (years) & 10.6 \\
Mean working capital (USD) & 25,500 \\
\% of self-funded working capital & 97 \\
Turnover period for rice stocks (days) & 9.7 \\
Contribution of rice to total sales (\%) & 100 \\
\% owning warehouse & 86 \\
\% renting warehouse & 33 \\
Mean area of warehouse (m ${ }^{2}$ ) & 63 \\
\% using trucks to deliver to retailers & 8 \\
\% using motorbikes to deliver to retailers & 100 \\
Average number of employees (persons) & 2.1 \\
\hline
\end{tabular}

Source: CASRAD survey, 2012 
Table 19.6 Characteristics of rice retailers in urban areas

\begin{tabular}{llll}
\hline Characteristics & $\begin{array}{l}\text { HCM City } \\
(\mathrm{n}=48)\end{array}$ & $\begin{array}{l}\text { Can Tho City } \\
(\mathrm{n}=37)\end{array}$ & $\begin{array}{l}\text { All } \\
(\mathrm{n}=85)\end{array}$ \\
\hline Mean age (years) & 32.5 & 31.0 & 31.8 \\
Gender (\% male) & 49 & 52 & 51 \\
Business experience in wet market (years) & 7 & 11 & 9 \\
Business experience outside wet market (years) & 8 & 8 & 8 \\
\% with stall in wet market & 38 & 49 & 42 \\
\% with shop in street & 62 & 51 & 58 \\
No. of years selling rice & 7.4 & 10.0 & 8.9 \\
Turnover of rice (kg/day) & 115 & 188 & 154 \\
Quantity of each purchase (kg) & 678 & 1386 & 1001 \\
Working capital (USD) & & & 1873 \\
\hline
\end{tabular}

Source: CASRAD survey, 2012

Table 19.7 Mode of selling rice by traditional retailers

\begin{tabular}{lr}
\hline Mode & $\%$ \\
\hline Rice sold in bulk with plastic bag provided & 99.2 \\
Rice sold in sacks or plastic bags & 0.8 \\
Packed without information & 99.2 \\
Packed with information about factories and brand & 0.8 \\
Packed with only information about factories & 0.0
\end{tabular}

Source: CASRAD survey, 2012

ers and many more selling rice in retail shops. The large number of sellers reduced the volume of sales in each business.

Almost all the traditional retailers sold rice in bulk and provided unlabelled plastic bags for customers to package the rice they bought (Table 19.7). While the variety, quality, and price of the rice could be assessed by the customers, there was no formal information provided about the origin, brand, and processing factory, hence no formal certification of the rice from Cambodia. Nevertheless, while domestic rice prices were in the range VND $11,000-13,000 / \mathrm{kg}$, the price of Cambodian rice was VND 5500-13,000/kg higher (Table 19.8). About half $(51 \%)$ of the consumers interviewed felt that Cambodian rice were of better quality than the domestically produced rice, and they preferred Soc products originating from Cambodia. 
Table 19.8 Retail prices of Cambodian specialty rice in Vietnamese market

\begin{tabular}{ll}
\hline Type & Retail price $(\mathrm{VND} / \mathrm{kg})$ \\
\hline Soc (traditional Cambodian varieties) & $17,000-19,000$ \\
Khaodak & $16,500-18,500$ \\
Jasmine & $17,000-19,500$ \\
Phuong Hoang & $23,000-26,000$ \\
\hline
\end{tabular}

Source: Survey 2012

\section{Impact of Cross-Border Trade on the Rice Market IN VIETNAM}

Vietnam is one of the world's largest rice exporters. Increasing imports from Cambodia add to the supply of rice for the domestic market and hence increase the export capacity (as well as directly adding to rice exports). The import of Cambodian rice also helps to meet the demand for specialty rice in Vietnam as consumer preference for higher-quality products increases. There are many different kinds of rice in the market in Vietnam and rice imported from Cambodia has contributed to the diversification of products available in the domestic market.

However, there have also been some negative impacts. The increase in cross-border trade has pushed down the domestic price, affecting the income of rice farmers in the border areas. In fact, many collectors in the border region only deal in imported paddy from Cambodia because this gives a higher profit. Hence, some Vietnamese farmers cannot sell their paddy at the domestic price due to the pressure of competition from Cambodia. In Can Tho City and Ho Chi Minh City, 50\% of rice retail stores sell varieties of rice originating from Cambodia. Though the price is higher than the price of domestically produced rice, the consumption of rice originating from Cambodia is very large and it is a competitive product with other specialty rice in the country. Vietnamese farmers also produce rice of high quality but the activities of marketing, product branding, and providing product information to domestic consumers are weak. This aspect of the value chain could be strengthened to improve the local product's position in the domestic market.

As noted above, large volumes of Cambodian paddy are imported into Vietnam via informal trade networks. Given that the price is lower than the domestic price, variations in the cross-border flow have led to price fluctuations in the Vietnamese market. Also, it has become difficult for the 
industry to identify and manage the supply of rice for the domestic market and for export. Coordination is needed between Vietnam and Cambodia to better manage paddy imports into Vietnam, limiting the large volume of paddy entering through informal trade (MIT 2008; Vo 2010).

\section{CONClusion}

The cross-border trade in paddy from Cambodia to Vietnam, especially between Takeo and An Giang Provinces, has increased substantially in volume, reaching an estimated $1000 \mathrm{t}$ per day in the peak season of November-December. There are five main reasons for the growth of this trade: (1) the quality of the wet-season crop produced in Takeo meets domestic demand in Vietnam for this type of rice; (2) some An Giang farmer-traders rent land for cultivation in Cambodia and transport paddy into Vietnam for the domestic market; (3) the harvest in Takeo is later than in An Giang, helping maintain the throughput of the rice mills in An Giang; (4) Cambodian paddy is cheaper than Vietnamese paddy of the same type; (5) Cambodia does not have sufficient capacity or technology for processing and storage, leading to a surplus of paddy that is exported to Vietnam.

There are three channels in the cross-border rice value chain, in which traders and paddy wholesalers provide the critical link: ( 1 ) from producers directly to Vietnamese traders $(5 \%)$; (2) from producers to Cambodian traders, who sell to Vietnamese traders (55\%); and (3) from producers to Cambodian traders who sell to Vietnamese paddy wholesalers, operating large granaries along the border $(40 \%)$. These granaries in turn sell to traders in Vietnam (55\%) and directly to processors (45\%). Processed rice is distributed to wholesalers in the cities or directly to numerous traditional retailers who operate market stalls or shops. While the Cambodian rice is identifiable to consumers, the mode of selling means there is no formal labelling or certification. Nevertheless, consumers pay a substantial premium for Cambodian rice-50-100\% over ordinary Vietnamese rice.

The large volume of paddy imported from Cambodia increases the supply of specialty rice for the domestic market in Vietnam. Demand for highquality rice is increasing in Vietnam as urban incomes increase. While domestic production cannot meet this demand, paddy imports from Cambodia are filling an important niche. They also free up more domestic rice for the export market. However, these cheaper paddy imports may also have a negative impact on domestic production and incomes, espe- 
cially in the border areas. It may be necessary to develop joint policies to manage better the cross-border trade. This could perhaps entail establishing joint-venture companies to purchase paddy from Cambodian farmers and facilitate processing in-country to export standards; ensuring that Vietnamese farmers in border areas are not adversely affected by the cheaper imports; and improving the commercial value of specialty varieties in Vietnam to meet domestic demand and increase farmers' incomes.

\section{Notes}

1. IR varieties have been bred by the International Rice Research Institute (IRRI) and OM varieties by the Cuu Long Delta Rice Research Institute at O Mon, Can Tho.

2. Cambodian Soc rice is a general name for any variety of traditional Cambodian wet-season (summer) rice, cultivated in an extensive manner.

\section{REFERENCES}

DARD (An Giang Province), 2011. Report on Agricultural Activities in An Giang Province. An Giang: Department of Agriculture and Rural Development.

GTZ, 2007. ValueLinks Manual: The Methodology of Value Chain Promotion. Eschborn: GTZ.

IFC 2015. Cambodia Rice: Export Potential and Strategies. Cambodia Agribusiness Series No. 4. Phnom Penh: International Finance Corporation.

Kaplinsky, R., and Morris, M., 2000. A Handbook for Value Chain Research. Ottawa: IDRC.

MIT, 2008. A Report on the Vietnam Border Trade with Cambodia, 2001-6. Hanoi: Ministry of Industry and Trade.

Purcell, T., 2010. Rice Production in Cambodia: Trends in Production and Productivity and Opportunities for Improvement. Phnom Penh: Agricultural Development International.

VFA, 2011. Anmual Activity Report of 2011. Ho Chi Minh City: Vietnam Food Association.

Vo Hung Dung, 2010. Improving the Value Chain of Rice Exports of Vietnam (Report). Can Tho City: Vietnam Chamber of Commerce and Industry. 
Open Access This chapter is licensed under the terms of the Creative Commons Attribution 4.0 International License (http://creativecommons.org/licenses/ by $/ 4.0 /$ ), which permits use, sharing, adaptation, distribution and reproduction in any medium or format, as long as you give appropriate credit to the original author(s) and the source, provide a link to the Creative Commons licence and indicate if changes were made.

The images or other third party material in this chapter are included in the chapter's Creative Commons licence, unless indicated otherwise in a credit line to the material. If material is not included in the chapter's Creative Commons licence and your intended use is not permitted by statutory regulation or exceeds the permitted use, you will need to obtain permission directly from the copyright holder.

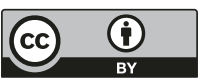

